Sharif University of Technology
Scientia Iranica
SCIENTIA
I RAN I C A
http://scientiairanica.sharif.edu

\title{
Application of ordinary fiber-reinforced concrete layer in in-plane retrofitting of unreinforced masonry walls: Test and modeling
}

\author{
S.M. Dehghan*, M.A. Najafgholipour, A.R. Kamrava, and M. Khajepour \\ Faculty of Civil and Environmental Engineering, Shiraz University of Technology, Shiraz, Iran.
}

Received 3 December 2016; received in revised form 23 May 2017; accepted 27 December 2017

\author{
KEYWORDS \\ Unreinforced \\ masonry; \\ Seismic retrofitting; \\ In-plane behavior; \\ Fiber reinforced \\ concrete; \\ Finite element \\ modeling.
}

\begin{abstract}
The masonry walls should have sufficient in-plane strength and stiffness to withstand the seismic loads during strong ground shakings. Different retrofitting techniques have been proposed for improving in-plane behavior of the unreinforced masonry (URM) walls. This study focuses on experimental evaluation and numerical simulation of a simple practical retrofitting technique employing Fiber Reinforced Concrete (FRC) surface layer. The simple FRC mix has conventional and available fiber, low fiber content, ordinary mix design, and applicable construction procedure. Effects of FRC mix properties, including fiber type, fiber content, and surface layer thickness, on in-plane behavior of masonry panels made up of conventional solid clay bricks are evaluated through experimental study in accordance with ASTM E-519 diagonal tension strength of masonry panels. In addition, a numerical simulation model for this retrofitting technique in ABAQUS software is proposed and validated with test results of bare and retrofitted panels.
\end{abstract}

(C) 2019 Sharif University of Technology. All rights reserved.

\section{Introduction}

Unreinforced masonry (URM) buildings are widely used in rural regions of developing countries. They have shown unsatisfactory seismic performance, costing many lives in the past earthquakes [1]. Masonry walls mainly support gravity loads and perform as lateral load resisting system of the URM buildings; thus, they should have sufficient strength and stiffness to withstand the seismic loads during strong ground shaking. In this regard, several experimental and numerical studies have been carried out on the in-plane behavior of the masonry walls $[2,3]$, which consider three typical in-plane failure modes, namely diagonal

*. Corresponding author. Tel./Fax: +98-71-37277656 E-mail addresses: smdehghan@sutech.ac.ir (S.M. Dehghan); najafgholipour@sutech.ac.ir (M.A. Najafgholipour)

doi: $10.24200 /$ sci. 2018.20164 shear failure (the most common failure mode), sliding shear failure, and in-plane flexural failure.

Most of the existing URM buildings do not have enough lateral capacity, which makes them vulnerable in earthquakes. Therefore, enhancement of inplane behavior of the existing walls is the essential objective of any seismic retrofitting process for masonry buildings. Different retrofitting techniques have been proposed for improving in-plane strength and behavior of the URM walls $[4,5]$. Surface or nearsurface strengthening techniques are mostly used for this purpose. One of the common retrofitting methods for both in-plane and out-of-plane strengthening of URM walls is adding a reinforced shotcrete overlay to the existing masonry walls [6,7]. In Iran, this method is widely used for strengthening of the URM buildings, especially schools [8]. Advantages of this technique are ease of application, low cost, considerable increase in in-plane strength, and to some extent higher ductility of the retrofitted walls. The commonly used 
reinforcement in the shotcrete layer may be steel bars or welded wire. In a recent research, the in-plane behavior of URM panels retrofitted by micro concrete layer reinforced with Welded Wire Mesh (WWM) was investigated by Kadam et al [9] through a series of diagonal compression tests according to ASTM E51910 [10] on masonry panels with different reinforcement patterns.

Fiber Reinforced Polymer (FRP) has been utilized for strengthening of existing URM walls. There are extensive experimental and numerical researches on the in-plane retrofitting of URM walls and infills with different types of FRP laminates [11-15]. El-Diasity et al. [16] investigated the in-plane behavior of confined masonry walls retrofitted using low-cost ferrocement and Glass Fiber Reinforced Polymer (GFRP) systems through cyclic in-plane tests. The in-plane behavior of URM walls retrofitted by near-surface-mounted FRP or twisted steel bars has also been addressed by a number of researchers $[17,18]$. Some researchers have used fabric-reinforced-cementitious-matrix, polymer Textile Reinforced Mortar (TRM) overlay, or polymeric net reinforced cementitious matrix for in-plane strengthening of URM walls [19-25]. Some other types of retrofitting techniques are using pre-tensioned stainless steel ribbons [26], steel strips [27], and high strength steels chords [28].

Fiber Reinforced Concrete (FRC) is generally concrete containing uniformly distributed discrete fibers such as steel fiber, glass fiber, synthetic fibers, or natural fibers. Arisoy et al. [29] evaluated the behavior of masonry walls fabricated with three different brick types, namely solid, hollow, and high strength hollow brick, and externally strengthened with Poly Vinyl Alcohol (PVA) fiber reinforced cement plaster. Uniaxial compression and diagonal tensile tests were used for this purpose. The results obtained from diagonal tension tests indicated that retrofitting masonry walls with fiber reinforced cement plaster increased the shear strength of the wall approximately 0.5 to 2.5 times depending on the brick type.

Among the innovative construction materials, Engineered Cementitious Composite (ECC) as a superior class of FRC with higher strain capacity and tensile strength, resulting in a semi-ductile construction material, is also used for strengthening of URM walls. The ECC layer is applied through shotcreting or hand troweling on the existing wall. Different types of fibers such as polypropylene (PP), Poly Vinyl Alcohol (PVA), and steel fibers with various shapes and strengths are used for reinforcing the concrete layer. Experimental and numerical researches have been carried out on in-plane and out-of-plane retrofitting of masonry walls by this method. Lin et al. [30,31] investigated the effectiveness of ECC overlay as an external reinforcement in the inplane shear behavior of $1.2 \mathrm{~m} \times 1.2 \mathrm{~m}$ panel of the
URM walls in an experimental study based on ASTM E519 test method. FRC and ECC overlays are also used for strengthening of masonry infilled frames [32$35]$.

Most of the aforementioned proposed retrofitting techniques of the URM cannot be used in practice, especially in underdeveloped and developing countries with many vulnerable masonry buildings due to lack of trained workers, high cost, and construction difficulty. Thus, this study focuses on experimental evaluation of a simple practical retrofitting technique employing a simple FRC surface layer. The ordinary FRC mix used here has conventional and available fiber, low fiber content, ordinary mix design, and simple applicable construction procedure. Since the URM walls generally have low tensile strength and brick-mortar bond, which lead to poor in-plane behavior, the masonry walls that serve as the main seismic force resisting system should be retrofitted.

Major findings of several experimental studies on the in-plane behavior of the retrofitted URM walls are summarized as follows. Different retrofitting techniques, particularly reinforced shotcrete, FRC, and ECC overlays, lead to enhancement of in-plane strength and stiffness of the URM walls. However, slight enhancement of in-plane ductility has been reported, which is usually ignored due to the inherent brittle behavior and very short period of masonry structural systems. Diagonal tension (shear) test of masonry assemblage is employed by different researches as a measure for in-plane behavior of retrofitted masonry walls.

In this paper, the effects of FRC mix characteristics, including fiber type, fiber content, and layer thickness on in-plane behavior of masonry panels made up of conventional solid clay bricks are evaluated through a comprehensive experimental study in accordance with shear test on masonry assemblages (ASTM E519-10). The results of experimental tests are shear strength and load deformation of bare and retrofitted masonry panels subjected to monotonic in-plane loading. In addition, a numerical simulation model for this retrofitting technique in ABAQUS software is proposed and validated with the test results. Furthermore, the results of this study can be extended to in-plane upgrading of infill masonry walls.

\section{Test program}

An experimental program was conducted to find the mechanical properties of FRC mixes and assess inplane shear capacity of the retrofitted URM panels with different retrofitting schemes.

\subsection{Fiber reinforced concrete}

Two types of polypropylene (PP) fiber, i.e., white and 


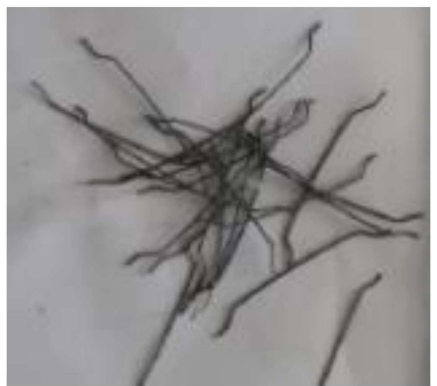

(a)

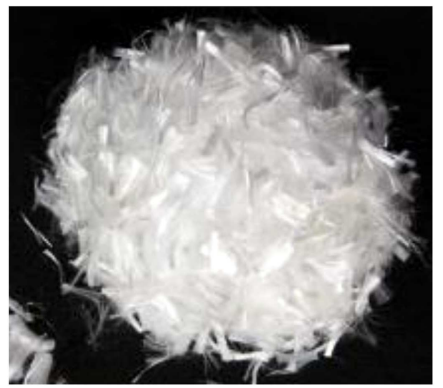

(b)

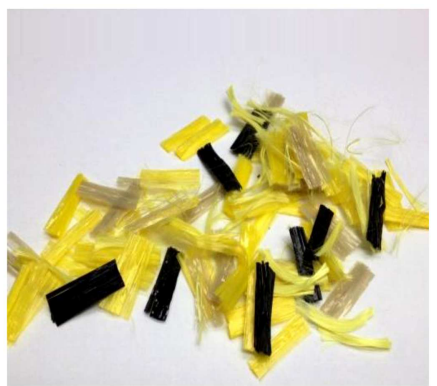

(c)

Figure 1. Steel and PP fibers: (a) Steel fiber, (b) white PP fiber, and (c) yellow PP fiber.

yellow PP fibers, and one type of hooked-end steel fiber, as shown in Figure 1, were used for reinforcing FRC mixes in this study. Properties of the fibers are presented in Table 1.

For in-plane strengthening of masonry panels, 6 different FRC mixes were utilized. Proportions of the FRC mixes including fiber type and fiber content are tabulated in Table 2. In one mix, steel and PP fibers are used in combination. The mix design was proportioned and the maximum aggregate size was limited to $4 \mathrm{~mm}$ to achieve sufficient workability, so the FRC paste could be applied through hand troweling or shotcreting. The same concrete mix, as shown in Table 3, was used for all the FRC mixes. The grading of the sand used in the FRC is shown in Figure 2.

\subsection{Standard test and mechanical properties of FRC mixes}

The compressive strength of $150 \times 150 \times 150 \mathrm{~mm}^{3}$ cubic samples of the FRC mixes was tested at the age of 28 days following BS EN 12390: 2009 [36]. The thirdpoint loading flexural strength of $150 \times 150 \times 500 \mathrm{~mm}^{3}$
Table 3. Concrete mix proportions.

\begin{tabular}{cccc}
\hline $\begin{array}{c}\text { Water } \\
\left(\mathbf{k g} / \mathbf{m}^{\mathbf{3}}\right)\end{array}$ & $\begin{array}{c}\text { Cement } \\
\left(\mathbf{k g} / \mathbf{m}^{\mathbf{3}}\right)\end{array}$ & $\begin{array}{c}\text { Aggregate } \\
\left(\mathbf{k g} / \mathbf{m}^{\mathbf{3}}\right)\end{array}$ & $\mathbf{W} / \mathrm{C}$ ratio \\
\hline 180 & 400 & 1780 & 0.45 \\
\hline
\end{tabular}

prism specimens of the FRC mixes was examined through ASTM C78-15 [37] procedure and modulus of rupture was obtained. Table 4 presents the average results of compressive and flexural tests of the FRC mixes.

The results of flexural tests show that adding steel fiber can improve rupture modulus of the FRC beam proportionally. In case of $\mathrm{PP}$ fiber, the white $\mathrm{PP}$ fiber adversely reduces the rupture modulus, while the yellow PP fiber slightly increases the rupture modulus. The combined fiber mix also shows some flexural strength improvement.

The compression tests reveal that adding the fiber does not generally increase the compressive strength of the FRC. This can be attributed to higher visible

Table 1. Physical and mechanical properties of fibers.

\begin{tabular}{cccccc}
\hline Designation & Fiber type & $\begin{array}{c}\text { Length } \\
(\mathbf{m m})\end{array}$ & $\begin{array}{c}\text { Diameter } \\
(\boldsymbol{\mu} \mathbf{m})\end{array}$ & Aspect ratio & $\begin{array}{c}\text { Tensile strength } \\
(\mathbf{M P a})\end{array}$ \\
\hline S & Steel & 50 & 300 & 45 & 600 \\
Y & PP - yellow & 19 & var & var & $490-2800$ \\
W & PP - white & $6-12$ & $23-35$ & var & $570-660$ \\
\hline
\end{tabular}

Table 2. Fiber type and content of FRC mixes.

\begin{tabular}{|c|c|c|c|c|}
\hline Designation & Description & Fiber type & $\begin{array}{l}\text { Fiber content } \\
\qquad\left(\mathrm{kg} / \mathrm{m}^{3}\right)\end{array}$ & $\begin{array}{c}\text { Fiber volume ratio } \\
(\%)\end{array}$ \\
\hline $\mathrm{P}$ & Plain & - & - & - \\
\hline S15 & FRC & Steel & 15 & 0.2 \\
\hline $\mathrm{S} 25$ & $\mathrm{FRC}$ & Steel & 25 & 0.3 \\
\hline Y3 & FRC & PP - yellow & 3 & 0.3 \\
\hline W3 & FRC & PP - white & 3 & 0.3 \\
\hline \multirow{2}{*}{ S15-Y3 } & \multirow{2}{*}{ FRC } & Steel & 15 & 0.2 \\
\hline & & PP - yellow & 3 & 0.3 \\
\hline
\end{tabular}


Table 4. Mechanical properties of the FRC mixes.

\begin{tabular}{ccc}
\hline Mix designation & $\begin{array}{c}\text { Compressive strength, } \\
\boldsymbol{f}_{\boldsymbol{c}}(\mathbf{M P a})\end{array}$ & $\begin{array}{c}\text { Modulus of Rupture, } \\
\boldsymbol{f}_{\boldsymbol{r}}(\mathbf{M P a})\end{array}$ \\
\hline P & 25.80 & 2.62 \\
$\mathrm{~S} 15$ & 19.93 & 3.20 \\
$\mathrm{~S} 25$ & 24.82 & 5.72 \\
$\mathrm{Y} 3$ & 19.95 & 2.92 \\
$\mathrm{~W} 3$ & 22.14 & 2.46 \\
$\mathrm{~S} 15-\mathrm{Y} 3$ & 22.48 & 3.66 \\
\hline
\end{tabular}

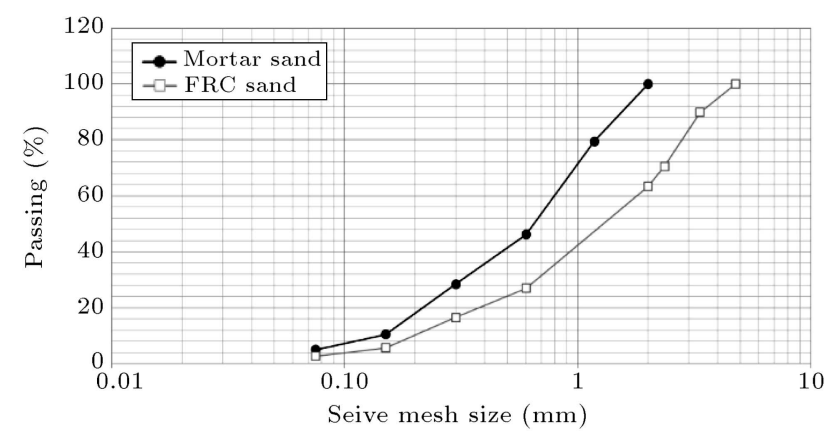

Figure 2. Grading of the sand used in FRC and mortar.

voids observed within the FRC. This phenomenon is not significant in the steel FRC.

\subsection{Masonry panels preparation}

In this study, regular solid clay bricks of Iran with average dimensions of $72 \times 105 \times 212 \mathrm{~mm}^{3}$ were employed. The average compressive and flexural strength of bricks were $17.1 \mathrm{MPa}$ and $3.8 \mathrm{MPa}$, respectively. For panel fabrication, the cement mortar with 1:3 (cement:sand) ratio was mixed to a workable consistency. Figure 2 shows mortar sand grading. The average compressive strength of $32 \mathrm{MPa}$ for cement mortar was determined in accordance with the requirements of Standard ASTM C270-14 [38].

The diagonal tension (shear) strength of masonry panels was evaluated based on ASTM E519-10 standard [10]. According to this standard, $1.2 \times 1.2 \mathrm{~m}^{2}$ masonry assemblages or smaller square specimens are loaded in compression along one diagonal, thus causing splitting failure parallel to the direction of load as shown in Figure 3.

A total number of 30 eight-course $660 \times 660 \mathrm{~mm}^{2}$ masonry panels, as shown in Figure 4, were prepared. Six bare specimens (not strengthened) were tested, while for each strengthening case, 4 specimens were fabricated of which at least 3 were tested. The mortar joint thickness was approximately 10-12 mm. For fabricating the masonry prism, bricks saturated with dry-surface were used and then, the masonry prisms were kept under plastic cover sealed to maintain humidity during 28 days of curing.

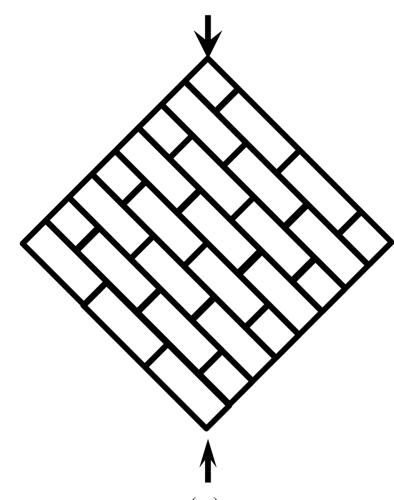

(a)

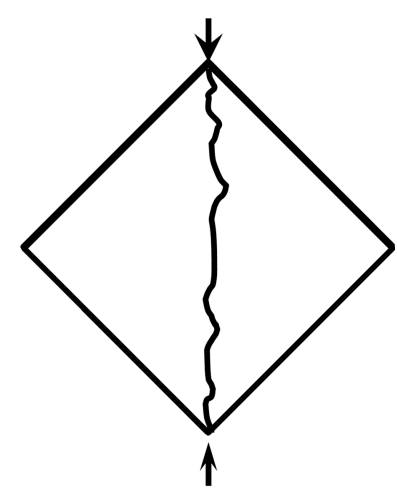

(b)
Figure 3. Diagonal tension or shear strength of masonry panel test: (a) Diagonal loading and (b) typical splitting failure mode.

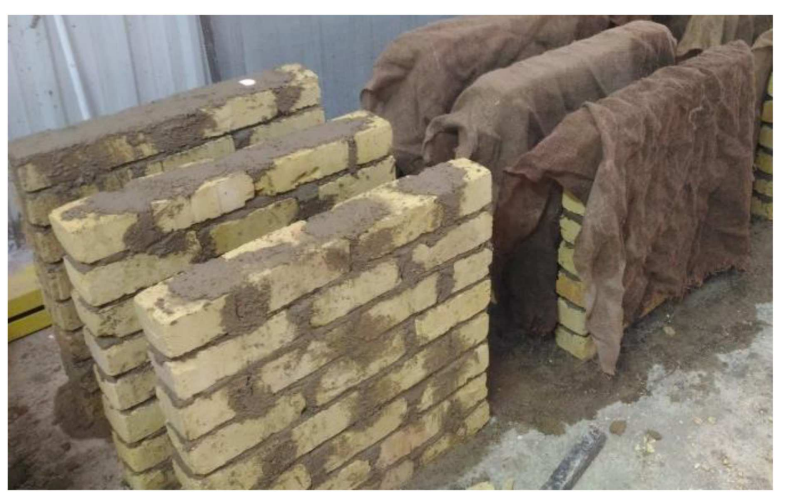

Figure 4. Unreinforced masonry panel.

After 28 days of curing, the FRC retrofitting layers were applied to both sides of the specimens. Sufficient amount of each FRC mix was prepared in a batch and hand troweled onto each surface of the masonry panel. To investigate the effect of retrofitting layer thickness, the surface layer with 25 or $40 \mathrm{~mm}$ thickness was applied; it was achieved by means of two steel rulers fixed on both sides of the specimen (see Figure 5). The 25-mm layer was prepared in a single pass, but the 40-mm layer was applied in two consequent passes to avoid falling down of the fresh FRC. The retrofitted specimens were further cured in another period of 28 days as described before. 


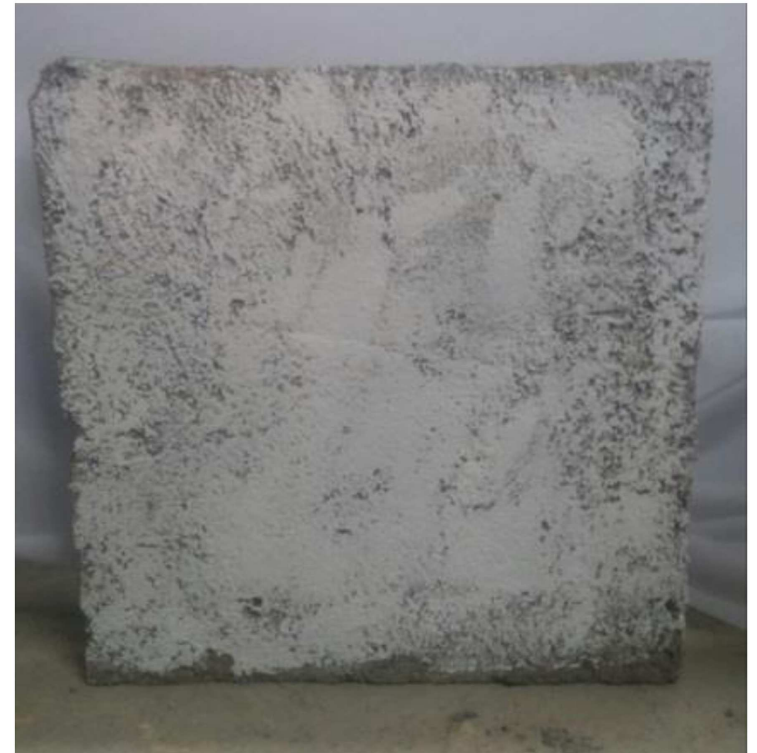

Figure 5. Retrofitted URM panel.

\subsection{Test procedure for retrofitted masonry specimens}

The parameters considered in the experimental study are fiber type, fiber content, and the thickness of the retrofitting layer. For this purpose, 9 types of retrofitting schemes as listed in Table 5 were assessed. The steel fiber was used with $0.2 \%$ and $0.3 \%$ volume ratios (15 and $25 \mathrm{~kg} / \mathrm{m}^{3}$, respectively), and the $\mathrm{PP}$ fibers (white or yellow PP fiber) were used with 0.3 volume ratio $\left(3 \mathrm{~kg} / \mathrm{m}^{3}\right)$. In one scheme, the yellow PP fiber and steel fiber were used in combination. The designation of the retrofitting schemes in Table 5 is used in the rest of this paper.

The diagonal tension test on masonry panels according to ASTM E519-10 [10] was extensively used

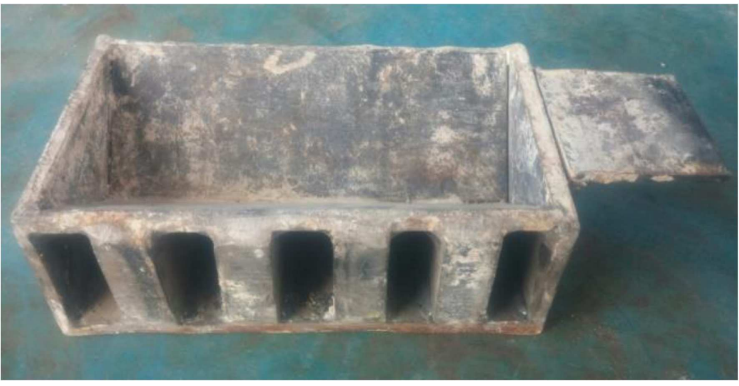

Figure 6. Steel loading shoe.

for measuring shear strength of masonry [39]. The loading system should have sufficient compressive load capacity and provide the required load rate. In accordance with the details of ASTM E519-10, two steel loading shoes as presented in Figure 6 were used to apply load to the specimens. The compressive load along one diagonal of square panels was applied monotonically by a hydraulic jack and measured by a load cell, as depicted schematically in Figure 7 . The diagonal deformation parallel to loading direction was measured by a digital displacement transducer at each load step. The in-plane shear strength was reported for each specimen and load-displacement curve up to the ultimate strength was measured for some specimens.

\section{Test results and discussion}

The ultimate shear strength and load-deflection of the masonry panels obtained by the tests are discussed here.

\subsection{Unreinforced masonry panels}

Average in-plane shear capacity of 6 bare masonry panels (unreinforced) was $36.6 \mathrm{kN}$. Based on ASTM

Table 5. FRC retrofitting schemes.

\begin{tabular}{ccccc}
\hline $\begin{array}{c}\text { Retrofitting } \\
\text { designation }\end{array}$ & $\begin{array}{c}\text { Thickness of } \\
\text { layer } \mathbf{( m m )}\end{array}$ & $\begin{array}{c}\text { Type of } \\
\text { fiber }\end{array}$ & $\begin{array}{c}\text { Fiber content } \\
\left(\mathbf{k g} / \mathbf{~ m}^{\mathbf{3}}\right)\end{array}$ & $\begin{array}{c}\text { Fiber volume } \\
\text { ratio (\%) }\end{array}$ \\
\hline Bare & - & - & - & - \\
T25-P & 25 & Plain & - & - \\
T25-S15 & 25 & Steel & 15 & 0.2 \\
T25-S25 & 25 & Steel & 25 & 0.3 \\
T25-W3 & 25 & PP-white & 3 & 0.3 \\
T25-Y3 & 25 & PP-yellow & 3 & 0.3 \\
& & & & 0.2 \\
T25-S15Y3 & 25 & Steel & 15 & 0.3 \\
& & PP-yellow & 3 & 0.2 \\
T40-S15 & 40 & Steel & 15 & 0.3 \\
T40-W3 & 40 & PP-white & 3 & \\
\hline
\end{tabular}




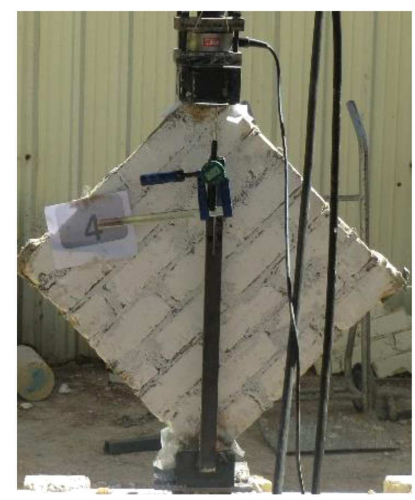

(a)

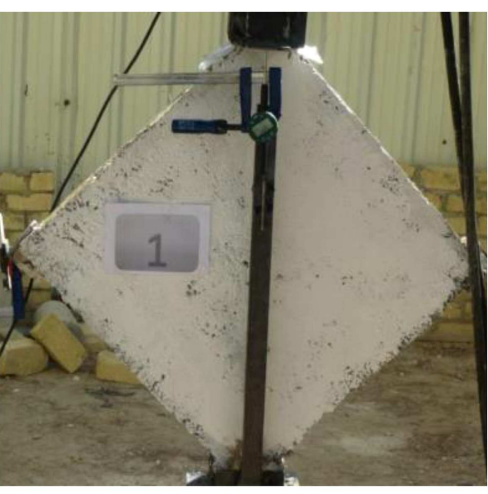

(b)

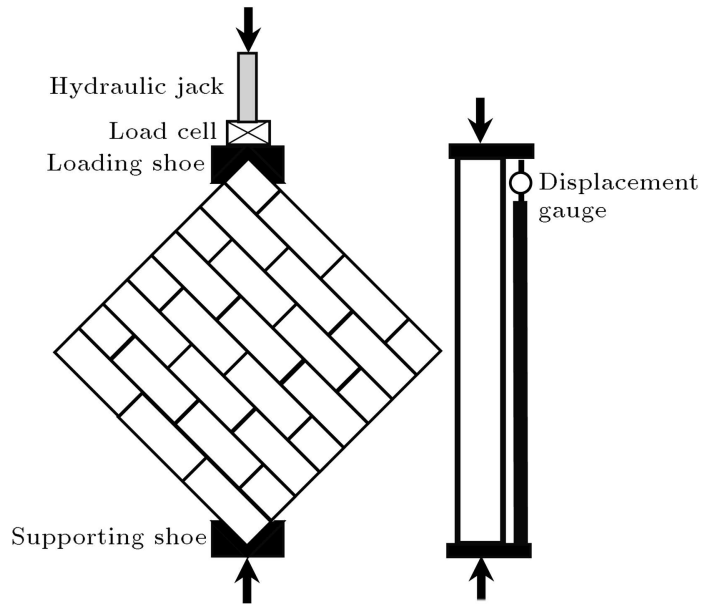

(c)

Figure 7. Diagonal tension test setup: (a) Bare prism, (b) retrofitted prism, and (c) schematic test setup.
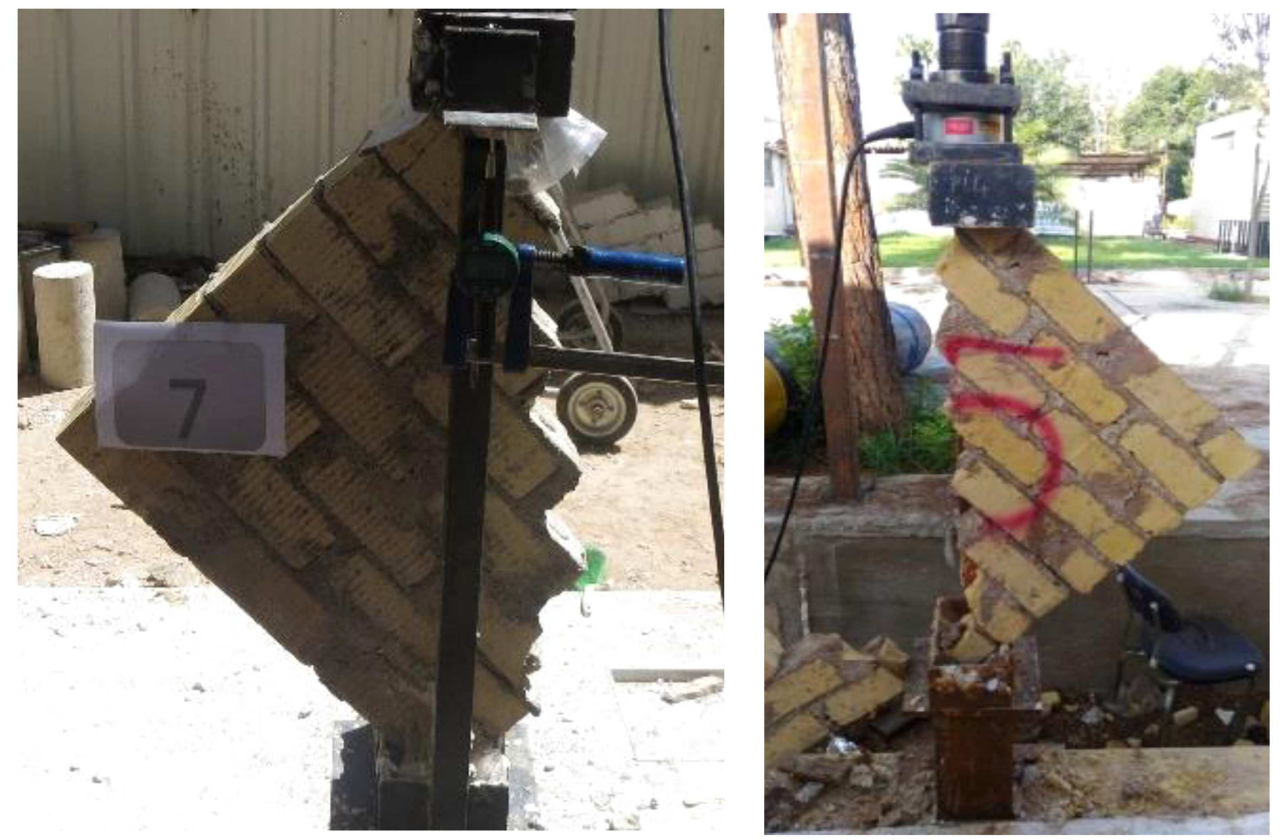

Figure 8. Typical failure mode of URM panel.

E519M-15, the shear stress can be computed as follows:

$$
S_{s}=\frac{0.707 P}{A_{n}}
$$

where $S_{s}$ is shear stress on net area (MPa), $P$ is the applied load $(\mathrm{N})$, and $A_{n}$ is net area of the specimen $\left(\mathrm{mm}^{2}\right)$, which is calculated as:

$$
A_{n}=\left(\frac{w+h}{2}\right) t n,
$$

where $w, h, t$, and $n$ are respectively width of specimen $(\mathrm{mm})$, height of specimen $(\mathrm{mm})$, total thickness of specimen $(\mathrm{mm})$, and percent of solid area of brick units. Thus, shear strength of bare panels composed of solid bricks $(n=1)$ is $0.528 \mathrm{MPa}$. The failure mode of unreinforced masonry panels is completely brittle, where diagonal crack forms with usually stepwise pattern as demonstrated in Figure 8.

\subsection{Retrofitted masonry panels}

The ultimate in-plane diagonal tension strength of retrofitted masonry panels is presented in Table 6 . The results are the averages for 3 tested retrofitted prisms. The corresponding shear stress is computed using Eqs. (1) and (2) where $t$ is the total thickness of the masonry prism and surface layers.

Adding strengthening surface layer considerably 
Table 6. Maximum in-plane load capacity of retrofitted masonry prisms.

\begin{tabular}{ccc}
\hline Retrofitting designation & $\begin{array}{c}\text { Shear strength } \\
(\mathbf{k N})\end{array}$ & $\begin{array}{c}\text { Ultimate shear stress } \\
(\mathbf{M P a})\end{array}$ \\
\hline T25-P & 168.3 & 1.163 \\
T25-S15 & 202.6 & 1.400 \\
T25-S25 & 220.1 & 1.522 \\
T25-W3 & 166.2 & 1.149 \\
T25-Y3 & 172.7 & 1.194 \\
T25-S15Y3 & 194.4 & 1.344 \\
& & \\
T40-S15 & 263.0 & 1.523 \\
T40-W3 & 236.1 & 1.367 \\
\hline
\end{tabular}
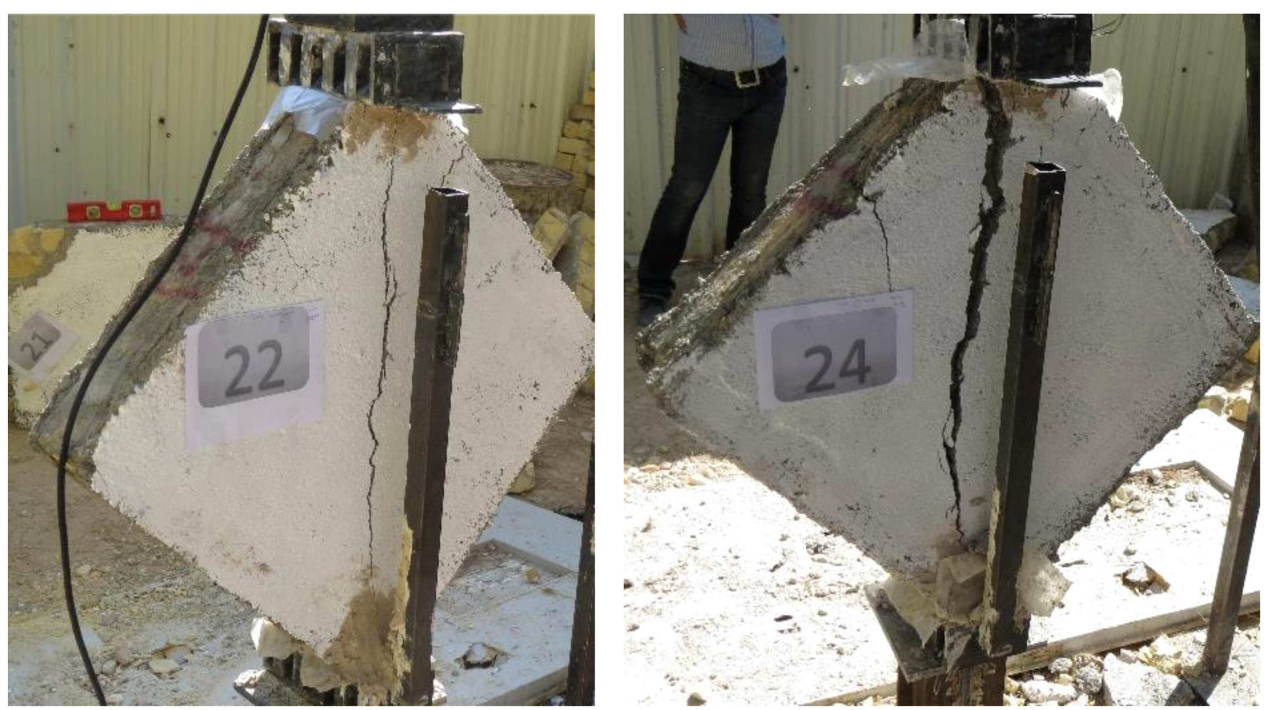

Figure 9. Crack opening of steel FRC layer.

increases the in-plane capacity of the bare masonry prism. The ultimate shear capacity depends on type of fiber, fiber content, and thickness of the FRC layer. Adding plain concrete surface layer with $25 \mathrm{~mm}$ of thickness resulted in in-plane load capacity of 168.3 $\mathrm{kN}$. In practice, this strength enhancement may not be achieved, mainly due to formation of thermal and shrinkage cracks in retrofitting layer and probability of layer debonding; thus, adding fiber to avoid thermal and shrinkage cracking seems necessary. Adding the PP fiber does not noticeably increase shear strength; contrarily, for white fiber, slight decrease can be observed. In case of using steel fiber, raising fiber content can efficiently improve in-plane strength of plain concrete $20.3 \%$ higher for T15-S15 and $30.7 \%$ higher for T25-S25 with respect to T25-P). Combined steel and PP fiber mix design T25-S15Y3 has higher shear strength than T25-Y3 mix (12.5\%). The in-plane capacity ratios of masonry panel retrofitted with the same FRC mix, one having $40 \mathrm{~mm}$ of layer thickness and the other $25 \mathrm{~mm}$ for W3 and S15 FRC mixes, are 1.42 and 1.30 , respectively.

The failure mode of FRC layer containing PP fiber is typically brittle with sudden fracture. However, panels retrofitted with steel fiber layer show non-brittle failure with some degree of crack opening as shown in Figure 9, which is more noticeable for higher amounts of steel fiber content.

Figure 10 presents diagonal load versus diagonal shortening of the panels retrofitted with the thicknesses of 25 and $40 \mathrm{~mm}$ for steel fiber reinforced layer. For retrofitted prisms with steel fiber, some softening can be seen as load reaches approximately $50 \%$ inplane capacity. The secant $50 \%$ capacity stiffnesses of retrofitted prisms are $321.1,364.2$, and $470.5 \mathrm{MN} / \mathrm{m}$ for T25S15, T25S25, and T40S15, respectively. For 


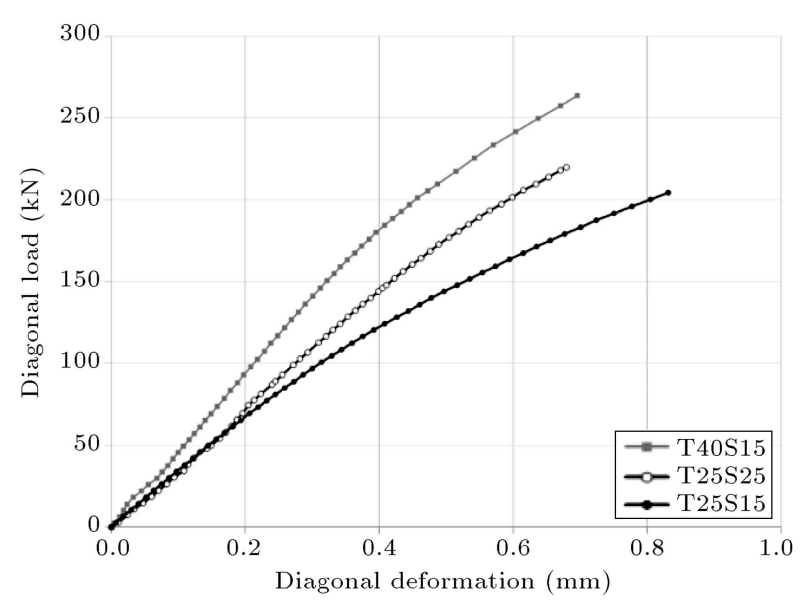

Figure 10. Diagonal load-deformation of retrofitted panels.

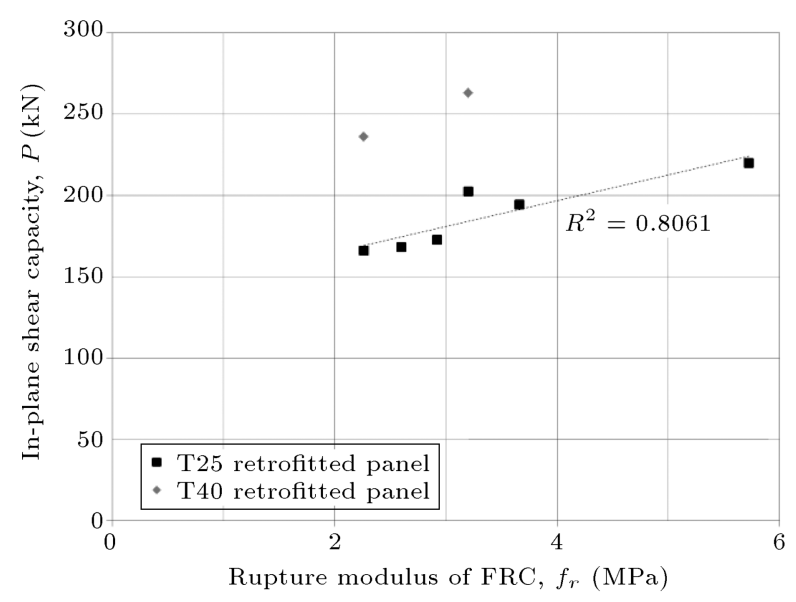

Figure 11. In-plane shear capacity of retrofitted panel versus rupture modulus of FRC mix.

steel FRC layer surface of $25 \mathrm{~mm}$, in-plane stiffness of $\mathrm{S} 25$ mix increases by $13 \%$ with respect to $\mathrm{S} 15 \mathrm{mix}$. Furthermore, the in-plane stiffness of the retrofitted prism with $\mathrm{S} 15$ surface layer of $40 \mathrm{~mm}$ is around 1.47 times that of $25 \mathrm{~mm}$ one.

\subsection{Comparing capacity of retrofitted panel with FRC properties}

Shear strength of the FRC mix is proportional to its tensile strength [40]. The ultimate in-plane shear capacity of retrofitted panels is plotted against flexural modulus, $f_{r}$, of the FRC mix in Figure 11. The linear trend for the 25-mm surface layer shows quiet sufficient accuracy in predicting in-plane shear capacity. To some extent, a similar trend can be observed for 40-mm surface layer.

\subsection{Effect of layer thickness on shear capacity of retrofitted panel}

The diagonal tension strength of W3 and S15 surface layers with 25 and $40 \mathrm{~mm}$ of thickness was tested as presented in Table 6. Figure 12 shows the influence of

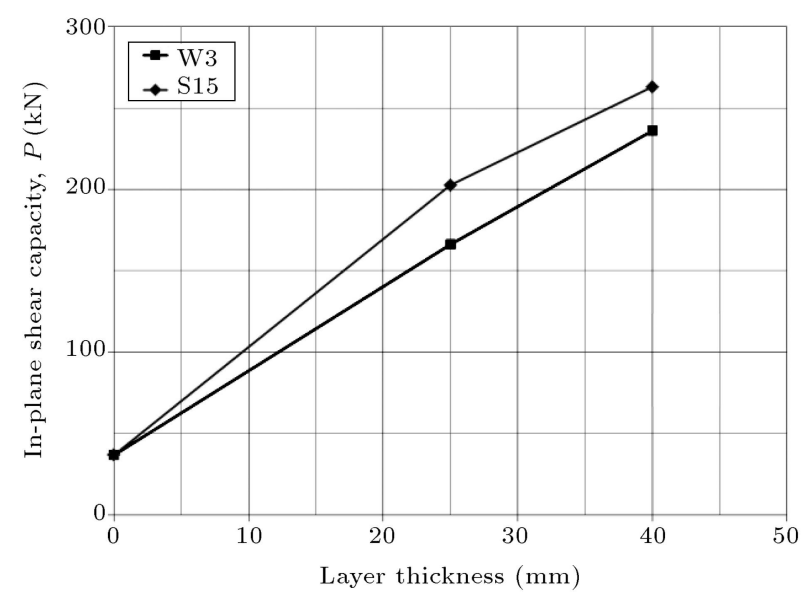

Figure 12. Effect of layer thickness on in-plane shear capacity of retrofitted panel.

layer thickness on in-plane shear capacity. Note that zero thickness layers correspond to the URM (bare) specimens.

\subsection{Predicting shear strength of retrofitted masonry with FRC overlay}

According to the test data presented in Table 6 and Figures 11 and 12, two practical equations are derived to predict shear strength of retrofitted masonry panels for FRC surface layers that are applied to both sides of the brickwork. For $25 \mathrm{~mm}$ of FRC layer, in-plane shear strength of the retrofitted panel $\left(P_{F R C 25}\right)$ in $\mathrm{kN}$ is:

$$
P_{F R C 25}=15.85 f_{r}+133.6,
$$

where $f_{r}$ is the rupture modulus of FRC mix in MPa following ASTM C78-15 [37] procedure, which indirectly represents the effect of type of fiber and fiber content of the FRC. For $40 \mathrm{~mm}$ of FRC layer, in-plane capacity of the strengthened panel $\left(P_{F R C 40}\right)$ in $\mathrm{kN}$ can be estimated as:

$$
P_{F R C 40}=28.62 f_{r}+171.4 .
$$

It should be noted that Eqs. (3) and (4) are valid if $f_{r}$ is within the range of 2 to $6 \mathrm{MPa}$.

\section{Numerical study}

In this section, a 3D finite element model in ABAQUS software for unreinforced masonry panels strengthened with FRC layer is presented. Finite element software such as Diana, ANSYS, and ABAQUS has been employed for modeling of unreinforced masonry buildings by a number of previous researchers $[41,42]$. Since micro modeling approach is utilized here, brick units, mortar joints, and brick mortar interfaces are modeled separately using appropriate constitutive models for each part. In retrofitted samples, FRC surface layers are also modeled separately. Considering the similarity 
of the brittle or semi-brittle behavior of masonry materials such as brick and mortar with concrete behavior, usually, constitutive models for concrete type materials have been used for modeling of masonry materials.

Generally, in finite element ABAQUS software, three methods are suggested to model the nonlinear behavior of concrete, i.e., discrete cracking model, smeared cracking model, and Concrete Damage Plasticity (CDP) model. Concrete Damage Plasticity (CDP) material model, which was proposed by Lee and Fenves in 1998 [43], is one of the most common constitutive models to simulate nonlinear behavior of brittle materials such as concrete. In this model, two failure mechanisms of tensile cracking and compressive crushing are considered. Appropriate failure surface is used in this model to address the effects of multiaxial stress effects. Concrete damages in tension and compression stress states are defined by scalar tensile damage index $(d t)$ and compressive damages index $(d c)$, respectively. These damage indices are a function of plastic strain that can take any values between 0 and 1 , where $\mathrm{dt}$ or $d c=0$ means undamaged material and $d t$ or $d c=1$ means completely damaged material. Figure 13 shows how the damage index is applied to the compressive and tensile stress-strain curves of concrete.

In this research, CDP model is used for modeling of brick units and mortar joints. For this purpose, a set of mechanical properties of brick units and mortar joints are required. These properties include modulus of elasticity, tensile strength, and compressive strength with appropriate stress-strain curves in tension and compression. Some properties may be obtained by standard material tests and the remaining properties may be estimated by the existing approximate relations.

Extensive research on shear behavior of brick mortar interface shows that brick mortar bond shear strength follows the Mohr-Coulomb Criterion, which

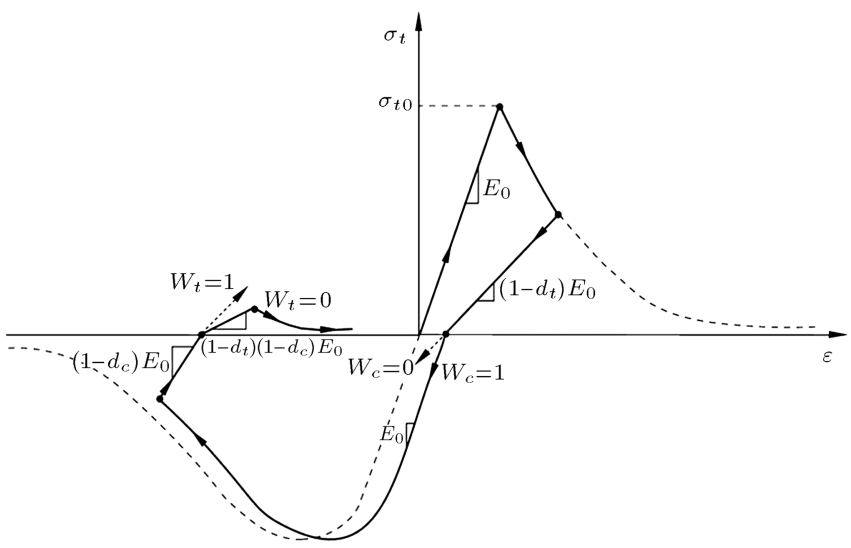

(a) is a combination of shear cohesion and frictional strength [45]. Therefore, in the current model, cohesive contact elements with frictional behavior in shear are used to model the brick-mortar interface.

\subsection{Verification of finite element model}

To verify the finite element model in this paper, four panels of specimens with in-plane behavior investigated in the experimental program were chosen and modeled according to the aforementioned modeling method. The tested specimens, i.e., T25-S15, T25-S25, and T40$\mathrm{S} 15$, with the available load-deformation data were used for verification. In addition, in-plane strengths of bare panel (Bare) and panel strengthened with plain concrete (T25-P) were compared with test result. Details of the modeling procedure are explained in this section.

- Geometry, loading, and boundary conditions of models. In the micro modeling approach used here, the components of the URM panels are simulated separately. These components include brick units, mortar joints, brick mortar interface, FRC retrofitting layer, and diagonal loading shoes. C3D8R eightnode 3D solid with maximum mesh size of $30 \mathrm{~mm}$ was employed for masonry units and surface layers. The element mesh size was determined after performing mesh sensitivity analysis. The same type of element was also used on modeling of steel shoes with appropriate mesh size. Figure 14 shows geometry of panels before and after retrofitting. The nodes of lower diagonal loading shoe were fixed in order to establish a suitable support for the specimen. Diagonal load was also applied by the other loading shoe according to the test set-up.

- Materials constitutive models. Since brittle behavior of brick, mortar, and FRC was similar to that of concrete, CDP constitutive model was used to

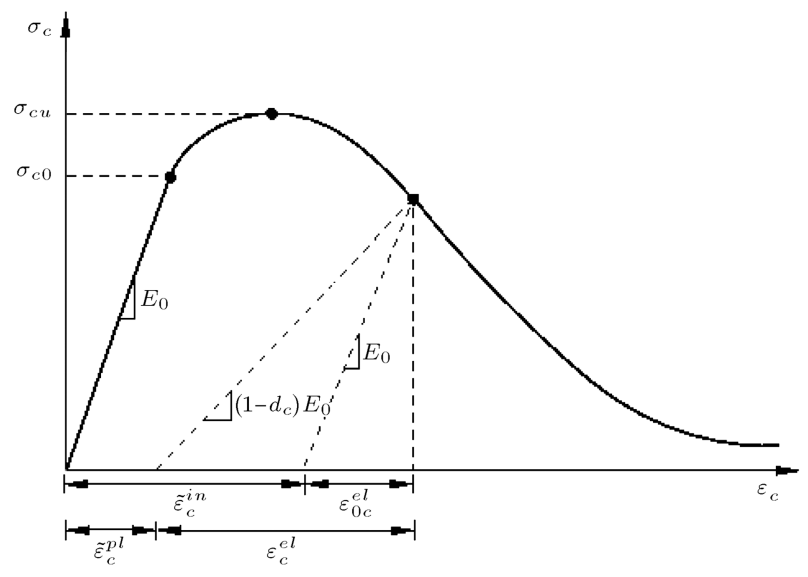

(b)

Figure 13. Appling damage index for stress-strain diagram of material [44]: (a) Damage in tension and (b) damage in compression. 


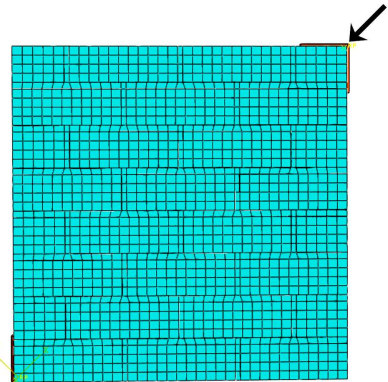

(a)

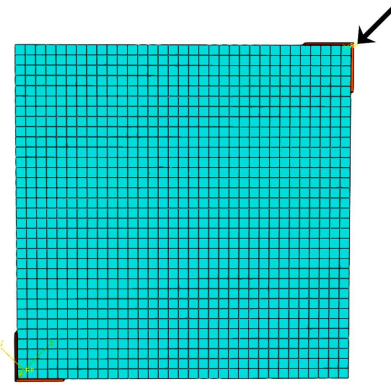

(b)
Figure 14. Geometry of panels: (a) Before retrofitting and (b) after retrofitting.

simulate the nonlinear behavior of different parts of retrofitted masonry panels. For each component, required mechanical properties should be estimated and applied to the model. Mechanical properties used here were chosen based on standard material tests in the experimental study program or recommended empirical relations. For this purpose, the aforementioned results for the flexural and compressive strength tests on brick, mortar, and FRC mixes were utilized for defining material behavior. It should be noted that to obtain direct tensile strength of materials from rupture modulus of flexural test, using 50 to $80 \%$ rupture modulus as tensile strength seemed reasonable [46], which depended on aggregate size to beam depth ratio.

To estimate modulus of elasticity of brick and mortar, approximate equations suggested by Kaushik et al. [47] were used. These equations, which are a function of compressive strength, are as follows:

$$
\begin{aligned}
& E_{m}=200 f_{m}, \\
& E_{b}=300 f_{b},
\end{aligned}
$$

where $E_{m}$ is the mortar modulus of elasticity, $E_{b}$ is the brick modulus of elasticity, and $f_{m}$ and $f_{b}$ are the compressive strengths of mortar and brick, respectively. To estimate FRC modulus of elasticity, the following equation recommended in ACI 31814 [48] for normal concrete was used:

$$
E_{c}=4700 \sqrt{f_{c}},
$$

where $E_{c}$ is the concrete modulus of elasticity, $w_{c}$ is the concrete specific weight $\left(1440 \leq w_{c} \leq 2650\right.$ $\mathrm{kg} / \mathrm{m}^{3}$ ), and $f_{c}$ is the concrete compressive strength.

Nonlinear stress-strain curves of masonry and its constituents such as brick and mortar obtained from tests in the literature are basically same as the stress-strain curves for concrete. Therefore, the stress-strain curve proposed by Hognestad [49] was used here for the ascending branch of brick units and mortar joints' stress-strain curves, while a linear descending branch up to the ultimate strain was adopted (see Figure 15). On the other hand, since stress-strain curve of FRC in compression was basically similar to that of normal concrete, the proposed curve by Kent and Park for unconfined concrete [50] was utilized (see Figure 15). However, the brick and mortar behaviors in tension were assumed linear up to the corresponding point of tensile strength and then, tended to zero stress with linear softening. In the case of FRC surface layer with rather ductile behavior in tension, the proposed model by Tan and Mansur [51] for FRC in tension, as depicted in Figure 16, was used.

For other parameters required to form the CDP model, either default or recommended values in references were used. One of these parameters was the dilation angle of materials. The value of this parameter could be between 30 to 42 degrees for materials similar to concrete. A summary of mechanical properties of materials used in the current finite element model is provided in Table 7 .

For defining the interface between brick and mortar, brick-mortar shear cohesion, tensile cohesion, and friction coefficient were required. Values of tensile and shear cohesions between brick and mortar were respectively $0.5 \mathrm{~N} / \mathrm{mm}^{2}$ and $0.1 \mathrm{~N} / \mathrm{mm}^{2}$, in accordance with the performed tests $[52,53]$ on

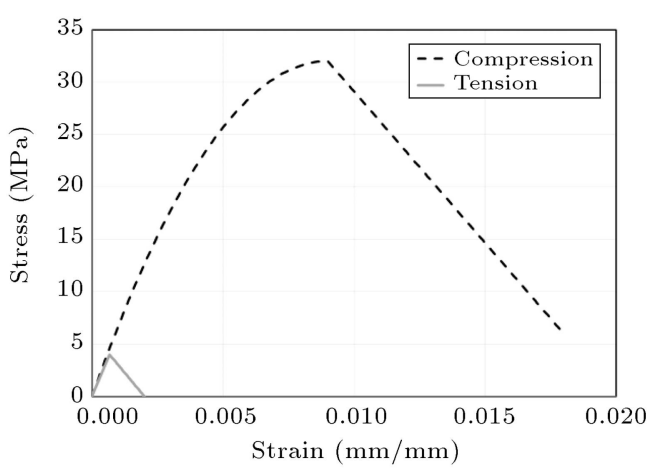

(a)

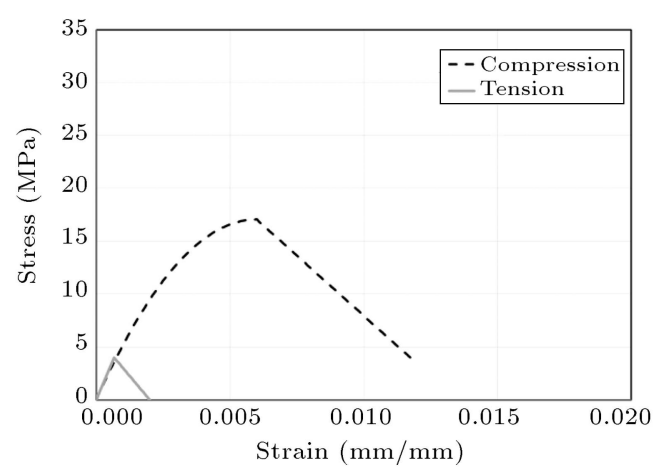

(b)

Figure 15. Stress-strain curves of mortar and brick: (a) Mortar and (b) brick. 


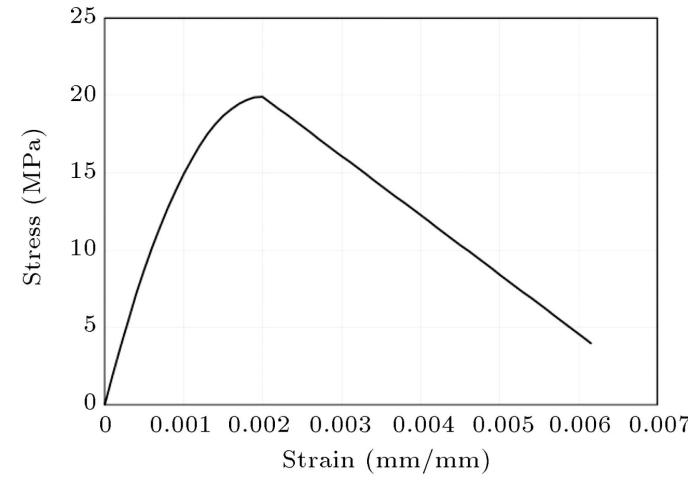

(a)

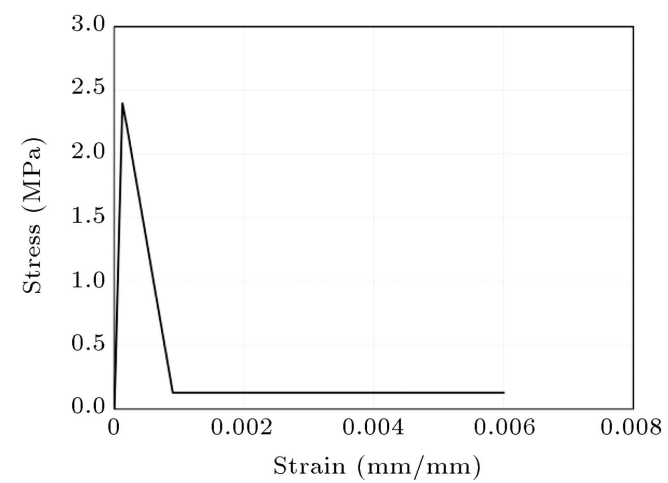

(b)

Figure 16. Stress-strain curves of FRC material: (a) Compressive behavior and (b) tensile behavior.

Table 7. Mechanical properties of materials used in numerical simulation.

\begin{tabular}{cccc}
\hline Material & $\begin{array}{c}\text { Compressive strength } \\
(\mathbf{M P a})\end{array}$ & $\begin{array}{c}\text { Elastic modulus } \\
(\mathbf{M P a})\end{array}$ & $\begin{array}{c}\text { Tensile strength } \\
\text { (MPa) }\end{array}$ \\
\hline Brick & 17.1 & 5130 & 3 \\
Mortar & 32 & 6400 & 4 \\
FRC-S15 & 19.9 & 18500 & 2.4 \\
FRC-S25 & 24.8 & 20600 & 3.1 \\
\hline
\end{tabular}

similar materials. Friction coefficient between brick and mortar was taken as 0.85 .

- Analysis method. There are two analysis algorithms in ABAQUS, explicit, and implicit. Explicit algorithm is particularly well suited for dynamic events or analyses with high level of nonlinearity. Also, it can be used for static analyses with complicated contact constraints. Therefore, explicit analysis with very low loading rate was used so that kinetic energy of structure model was a very small fraction of internal energy of the structure. Loading was performed as displacement control along the diameter of the sample until the ultimate failure. Load displacement curve and ultimate in-plane capacity were obtained from analyzes.

\subsection{Results of numerical modeling}

Force-displacement curves obtained from numerical analyses and performed tests for three retrofitted samples (T25S15, T25S25, and T40S15) are presented in Figure 17.

Figure 18 plots diagonal load-deflection of bare specimens. For the bare panel, load-deflection curve up to failure is almost linear. In-plane stiffness of the bare panel is around $32 \mathrm{MN} / \mathrm{m}$.

Distribution of principal stress in bare panel and T25-S15 retrofitted panels at ultimate state is

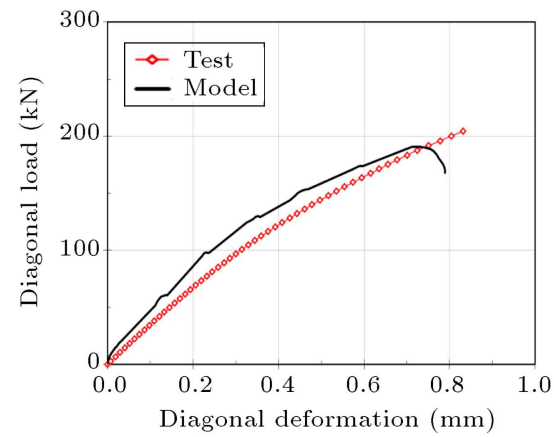

(a)

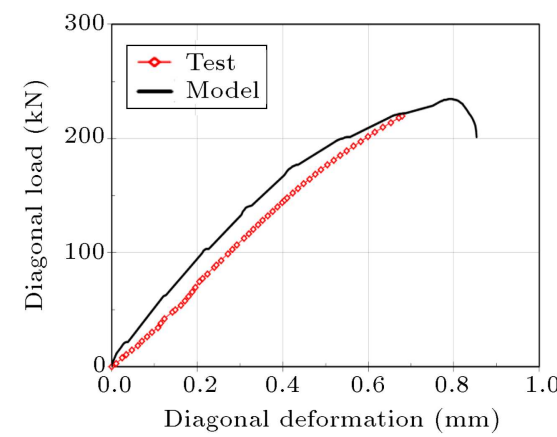

(b)

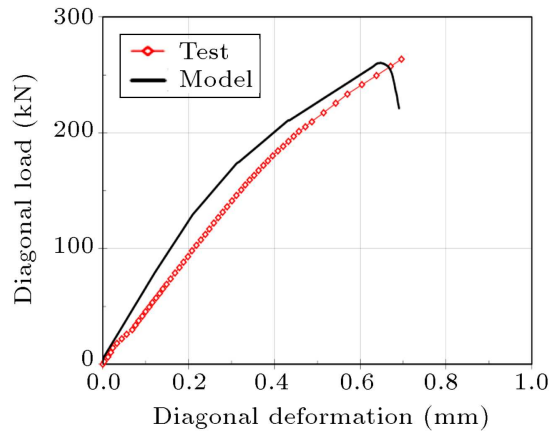

(c)

Figure 17. Comparison of diagonal load-deformation curves for numerical simulation and test: (a) T25S15, (b) T25S25, and (c) T40S15. 
Table 8. Summary of test and modeling of in-plane strength.

\begin{tabular}{cccc}
\hline Retrofit scheme & $\begin{array}{c}\text { Test shear strength } \\
\text { (MPa) }\end{array}$ & $\begin{array}{c}\text { Model shear strength } \\
\text { (MPa) }\end{array}$ & $\begin{array}{c}\text { Relative error } \\
(\%)\end{array}$ \\
\hline Bare & 36.6 & 31.6 & 14 \\
T25-P & 168.3 & 184.8 & 9.8 \\
T25-S15 & 202.6 & 190.7 & 5.9 \\
T25-S25 & 220.1 & 234.7 & 6.6 \\
T40-S15 & 263.0 & 260.3 & 1.1 \\
\hline
\end{tabular}

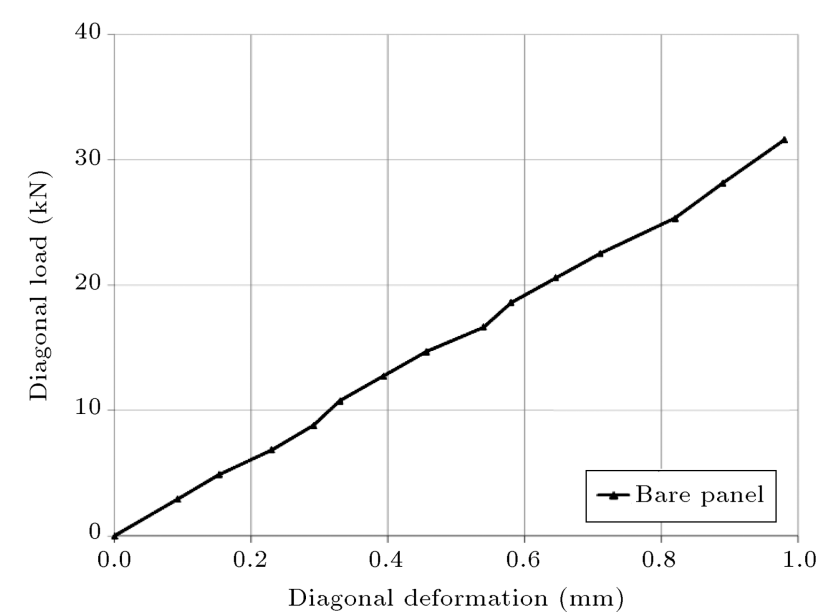

Figure 18. Diagonal load-deformation of bare panel.

presented in Figure 19. It is observed that the critical principal stress occurs along compression diagonal of the panels, which is in agreement with the reported diagonal cracking failure in tests.

Furthermore, ultimate strength of samples obtained from modeling and tests are listed in Table 8. As it is shown, numerical simulation can reasonably predict the ultimate in-plane strength of bare sample and different retrofitted panels, where the maximum relative difference is $14 \%$.

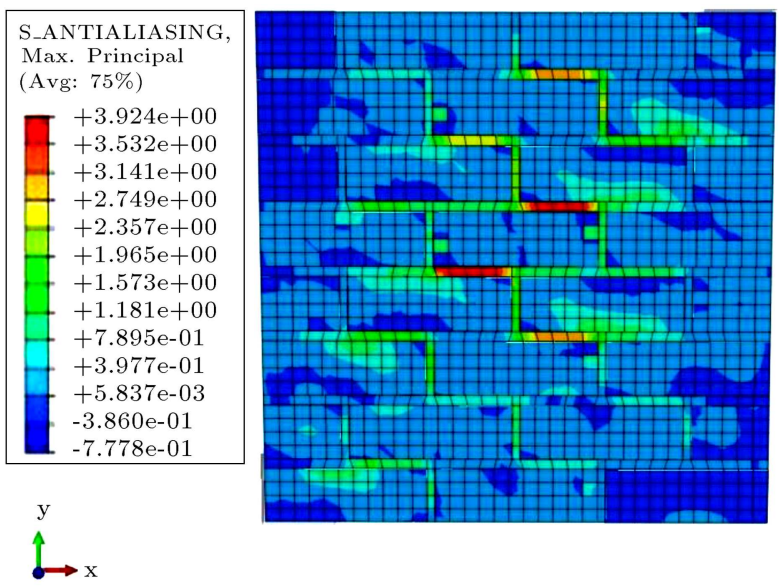

(a)

\section{Conclusions}

This paper presents results of an experimental study and numerical modeling of in-plane behavior of the URM panels retrofitted with fiber reinforced concrete surface layer. The tested retrofitting schemes included type of FRC mix (fiber type and fiber volume fraction) and thickness of surface layer. Diagonal tensile in-plane testing was performed on masonry square panels to find in-plane shear strength and load-displacement curves.

The test results for retrofitted panels and numerical simulation showed that:

- Adding FRC layer could significantly increase inplane capacity and stiffness;

- This capacity enhancement mainly depended on layer thickness and flexural strength of the FRC layer;

- Using PP fiber in the FRC layer could slightly increase in-plane capacity with respect to plain concrete layer; however, to avoid thermal and shrinkage cracking in retrofitted surface of masonry walls, adding a minimum $0.3 \%$ of PP fiber seemed to be necessary;

- In-plane strength of the URM panels could be effectively improved by means of steel fiber-reinforced concrete layer; thus, this simple and practical
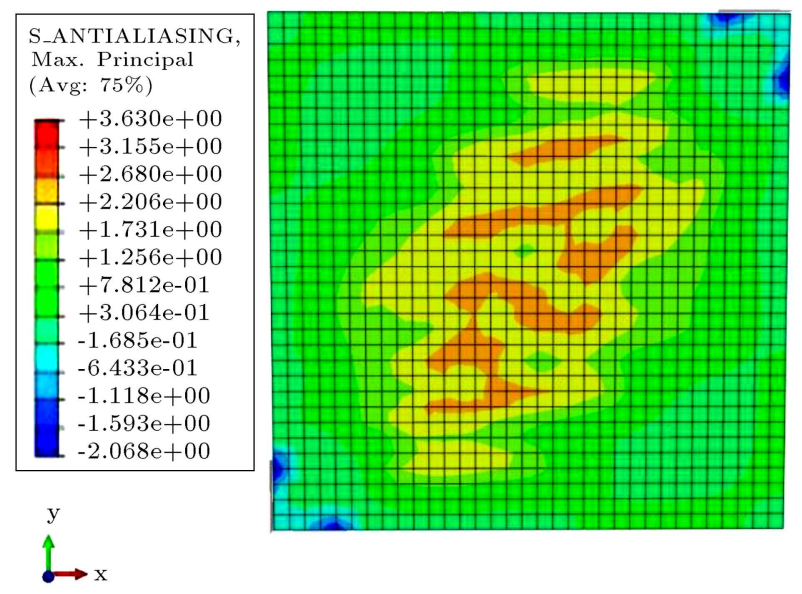

(b)

Figure 19. State of principal stress at ultimate in-plane load: (a) Bare panel and (b) T25-S15 retrofitted. 
retrofitting method can be used for seismic strengthening of the existing vulnerable masonry walls;

- Comparing in-plane strengths of PP and steel FRC layers indicated that with the same volume fraction of fiber, panels retrofitted with steel FRC had around $30 \%$ higher strength in average;

- A micro-modeling approach to numerical simulation of in-plane behavior of the URM panels was introduced and verified, which could reasonably represent behavior and in-plane capacity of bare and retrofitted panels;

- The significant enhancement of in-plane strength of masonry panels retrofitted by FRC layer can be similarly employed for upgrading of in-plane behavior of in-fill walls that are participating in lateral-load resisting systems.

\section{Acknowledgement}

The research project was financially supported by Fars Organization for Engineering Order of Building. This support is gratefully acknowledged.

\section{References}

1. FEMA P-774 "Unreinforced masonry buildings and earthquakes: Developing successful risk programs", Applied Technology Council (ATC), Redwood City, California (2009).

2. Da Porto, F., Guidi, G., Garbin, E., and Modena, C. "In-plane behavior of clay masonry walls: experimental testing and finite-element modeling", Journal of Structural Engineering, 136(11), pp. 1379-1392 (2010).

3. Eshaghi, S. and Sarrafi, B. "Effect of openings on lateral stiffness and strength of confined masonry walls", Scientica Iranica, Transaction A: Civil Engineering, 21(3), pp. 457-468 (2014).

4. ELGawady, M.A., Lestuzzi, P., and Badoux, M. "A review of conventional seismic retrofitting techniques for URM", 13th. International Brick and Block Masonry Conference, Amsterdam (2004).

5. Karantoni, F.V. and Fardis, M.N. "Effectiveness of seismic strengthening techniques for masonry buildings", Journal of Structural Engineering, 118(7), pp. 1884-1902 (1992).

6. ELGawady, M.A., Lestuzzi, P., and Badoux, M. "Retrofitting of masonry walls using shotcrete", NZSEE Conference, pp. 45-54 (2006).

7. Ghiassi, B., Soltani, M., and Tasnimi A.A. "Evaluation of masonry structures strengthened with reinforced concrete layers", Journal of Structural Engineering, 138, pp. 729-743 (2012).

8. Raissi Dehkordi, M., Yekrangnia, M., Eghbali, M., and Mahdizadeh, A.R. "Report for retrofit procedure of school buildings in Iran", 2nd European Conference on Earthquake Engineering and Seismology, Istanbul (2014).

9. Kadam, S.B., Singh, Y., and Li, B. "Strengthening of unreinforced masonry using welded wire mesh and micro-concrete - Behavior under in-plane action", Construction and Building Materials, 54, pp. 247-257 (2014).

10. American Society for Testing and Materials (ASTM), ASTM E 519-10. Standard Test Method for Diagonal Tension (shear) in Masonry Assemblages (2010).

11. ELGawady, M.A., Lestuzzi, P., and Badoux, M. "Aseismic retrofitting of unreinforced masonry walls using FRP", Composites: Part B, 37, pp. 148-162 (2006).

12. Luccioni, B. and Rougier, V.C. "In-plane retrofitting of masonry panels with fibre reinforced composite materials", Construction and Building Materials, 25, pp. 1772-1788 (2011).

13. Luccioni, B. and Rougier, V.C. "Numerical analysis of fibre reinforced polymer retrofitted masonry panels", Engineering Structures, 49, pp. 360-372 (2013).

14. Santa-Maria, H. and Alcaino, P. "Repair of in-plane shear damaged masonry walls with external FRP", Construction and Building Materials, 25, pp. 11721180 (2011).

15. Luccioni, B. and Rougier, V.C. "Shear behavior of brick-mortar interface in CFRP retrofitted or repaired masonry", International Journal of Mechanical Science, 52, pp. 602-611 (2010).

16. El-Diasity, M., Okail, H., Kamal, O., and Said, M. "Structural performance of confined masonry walls retrofitted using ferro cement and GFRP under inplane cyclic loading", Engineering Structures, 94, pp. 54-69 (2015).

17. Konthesingha, K.M.C., Masia, M.J., Petersen, R.B., Mojsilovic, N., Simundic, G., and Page, A.W. "Shear response of damaged masonry walls retrofitted with NSM FRP strips - An experimental evaluation", Engineering Structures, 50, pp. 126-136 (2013).

18. Ismail, N., Petersen, R.B., Masia, M.J., and Ingham, J.M. "Diagonal shear behavior of unreinforced masonry wallets strengthened using twisted steel bars", Construction and Building Materials, 25, pp. 43864393 (2011).

19. Ismail, N. and Ingham, J.M. "In-plane and out-ofplane testing of unreinforced masonry walls strengthened using polymer textile reinforced mortar", Engineering Structures, 118, pp. 167-177 (2016).

20. Basili, M., Maracari, G., and Vestroni, F. "Nonlinear analysis of masonry panels strengthened with textile reinforced mortar", Engineering Structures, 113, pp. 245-258 (2016).

21. Babaeidarabad, S., Arboleda, D., Loreto, G., and Nanni, A. "strengthening of un-reinforced concrete masonry walls with fabric-reinforced-cementitiousmatrix", Construction and Building Materials, 65, pp. 243-253 (2014). 
22. Papanicolau, C.G., Triantafillou, T., Karlos, K., and Papathantasiou, M. "Textile-reinforced mortar (TRM) versus FRP as strengthening material of URM walls: in-plane cyclic loading", Materials and Structures, 40, pp. 1081-1097 (2007).

23. Papanicolaou, C., Triantafillou, T., and Lekka, M. "Externally bonded grids as strengthening and seismic retrofitting materials of masonry panels", Construction and Building Materials, 25, pp. 504-514 (2011).

24. Baloevic, G., Radnic, J., Grgic, N., and Matesan, D. "The application of a reinforced plaster mortar for seismic strengthening of masonry structures", Composites Part B, 93, pp. 190-202 (2016).

25. D'Ambrisi, A., Mezzi, M., Feo, L., and Berardi, V.P. "Analysis of masonry structures strengthened with polymeric net reinforced cementitious matrix materials", Composite Structures, 113, pp. 264-271 (2014).

26. Spinella, N., Colajanni, P., and Recupero, A. "Experimental in situ behavior of unreinforced masonry elements retrofitted by pre-tensioned stainless steel ribbons", Construction and Building Materials, 73, pp. $740-753$ (2014).

27. Farooq, S.H., Shahid, I., and Ilyas, M. "Seismic performance of masonry strengthened with steel strips", KSCE Journal of Civil Engineering, 18(7), pp. 21702180 (2014).

28. Borri, A., Castori, G., and Corradi, M. "Shear behavior of masonry panels strengthened by high strength steel cords", Construction and Building Materials, 25, pp. 494-503 (2011).

29. Arisoy, B., Ercan, E., and Demir, A. "Strengthening of brick masonry with PVA fiber reinforced cement stucco", Construction and Building Materials, 79, pp. 255-262 (2015).

30. Lin, Y.W., Biggs, D., Wotherspoon, L., and Ingham, J.M. "In-plane strengthening of unreinforced concrete masonry wallettes using ECC shotcrete", Journal of Structural Engineering, 140(11), 04014081 (2014).

31. Lin, Y.W., Wotherspoon, L., Scott, A., and Ingham, J.M. "In-plane strengthening of clay brick unreinforced masonry wallettes", Engineering Structures, 66, pp. 57-65 (2014).

32. Sevil, T., Baran, M., Bilir, T., and Canbay, E. "Use of steel fiber reinforced mortar for seismic strengthening", Construction and Building Materials, 25, pp. 892-899 (2011).

33. Koutromanos, I., Kyriakides, M., Stavridis, A., Billington, S., and Shing, P. "Shake-table tests of a 3story masonry-infilled RC frame retrofitted with composite materials", Journal of Structural Engineering ASCE, 139, pp. 1340-1351 (2013).

34. Koutromanos, I. and Shing, P. "Numerical study of masonry-infilled RC frames retrofitted with ECC overlays", Journal of Structural Engineering ASCE, 140, pp. 1-12 (2014).
35. Dehghani, A., Nateghi-Alahi, F., and Fischer, G. "Engineered cementitious composites for strengthening masonry infilled reinforced concrete frames", Engineering Structures, 105, pp. 197-208 (2015).

36. BS EN 12390-2:2009, Testing Hardened Concrete. Making and Curing Specimens for Strength Tests (2009).

37. American Society for Testing and Materials (ASTM), ASTM C 78M-15. Standard Test Method for Flexural Strength of Concrete (Using Simple Beam with ThirdPoint Loading) (2015).

38. American Society for Testing and Materials (ASTM), ASTM C 270-14. Standard Specification for Mortar for Unit Masonry (2014).

39. Najafgholipour, M.A., Maheri, M.R., and Lourenço, P.B. "Capacity interaction in brick masonry under simultaneous in-plane and out-of-plane loads", Construction and Building Materials, 38, pp. 619-626 (2013).

40. Kwak, Y.K., Eberhard, M.O., Kim, W.S., and Kim, J. "Shear strength of steel fiber-reinforced concrete beams without stirrups", ACI Structural Journal, 99(4), pp. 530-538 (2002).

41. Maheri, M.R., Najafgholipour, M.A., and Rajabi, A.R. "The influence of mortar head joints on the in-plane and out-of-plane seismic strength of brick masonry walls", Iranian Journal of Science and Technology, 35(C1), pp. 63-79 (2011).

42. Agüera, N.D., Tornello, M.E., and Frau, C.D. "Structural response of unreinforced masonry walls", Journal of Civil Engineering and Architecture, 10, pp. 219-231 (2016).

43. Lee, J. and Fenves, G.L. "Plastic damage model for cyclic loading of concrete structures", Journal of Engineering Mechanics (ASCE), 124(8), pp. 892-900 (1998).

44. ABAQUS Analysis user's manual 6.10-EF, Dassault Systems Simulia Corp., Providence, RI, USA (2010).

45. Abdou, L., Saada, R.A., Meftah, F., and Mebarki, A. "Experimental investigations of the joint-mortar behaviour", Mechanics Research Communications, 33(3), pp. 370-384 (2006).

46. Bazant, Z.P. and Li, Z. "Modulus of rupture: size effect due to fracture initiation in boundary layer", Journal of Structural Engineering (ASCE), 121(9), pp. 728-739 (1995).

47. Kaushik, H.B., Durgesh, C.R., and Sudhir K.J. "Stress-strain characteristics of clay brick masonry under uniaxial compression", Journal of Materials in Civil Engineering (ASCE), 19(9), pp. 728-739 (2007).

48. ACI 318-14, Building Code Requirements for Structural Concrete and Commentary, American Concrete Institute (2014). 
49. Hognestad, E., A Study of Combined Bending and Axial Load in Reinforced Concrete Members, University of Illinois Engineering Experiment Station, Bulletin No. 399 (1955).

50. Kent, D.C. and Park, R. "Flexural members with confined concrete", Journal of Structural Division, Proceedings of American Society of Civil Engineers, 97(ST7), pp. 1969-1990 (1971).

51. Tan, K.H. and Mansur, M.A. "Shear transfer in reinforced fiber concrete", Journal of Materials in Civil Engineering ( $A S C E), 2(4)$, pp. 202-214 (1990).

52. Mazroi, A., Yaghoubifar, A., Majedi Ardakani, M.H., Zeidabadi Nejad, E., and Jafarpour, F. "Experimental study of mechanical properties of common sand and cement mortar (for masonry)", Research Report, BHRC Publication, Tehran, Iran (2012).

53. Najafgholipour, M.A. "The effect of lack of mortar in head joints on the in-plane shear strength of unreinforced brick walls", M.Sc. Thesis, Shiraz University, Iran (2007).

\section{Biographies}

Seyed Mehdi Dehghan is an Assistant Professor in the Civil and Environmental Engineering Department at Shiraz University of Technology. He received BSc and MSc degrees from Shiraz University. Moreover, he received his $\mathrm{PhD}$ degree in Structural Engineering from Tohoku University, Japan, in 2008. His research interests include seismic behavior of steel, RC, and masonry structures; passive control of structures; and seismic isolation.

Mohammad Amir Najafgholipour is an Assistant Professor in the Civil and Environmental Engineering Department at Shiraz University of Technology. He received $\mathrm{BSc}, \mathrm{MSc}$, and $\mathrm{PhD}$ degrees from Shiraz University in 2004, 2007, and 2012, respectively. He also had a sabbatical visit in Minho University, Portugal, in 2011. His main areas of research interest are seismic performance evaluation and retrofitting of existing buildings, and experimental and numerical studies on masonry and RC structures. He now serves as a committee member of Iranian National Building Code for Design and Construction of Masonry Buildings.

Alireza Kamrava is currently a $\mathrm{PhD}$ candidate in the Civil Engineering Department at Islamic Azad University, Najafabad Branch. He received his MSc degree from Shiraz University of Technology in 2016. He is interested in masonry structures and numerical studies on their behavior and rehabilitation.

Mehrdad Khajepour received MSc degree in Earthquake Engineering from Shiraz University of Technology in 2015. He is interested in seismic performance, and evaluation and rehabilitation of masonry buildings. 